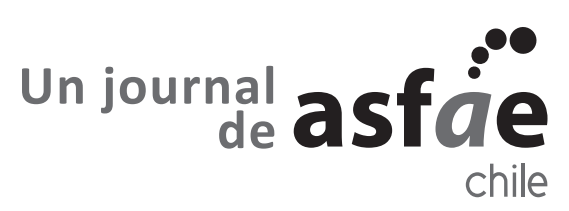

\title{
“MORE DAVIDS THAN GOLIATHS?” A CASE FOR THE POWER OF SMALL FIRMS TO BE STRONGER INNOVATORS COMPARED TO LARGER FIRMS DURING A GLOBAL PANDEMIC
}

\author{
¿MÁS DAVIDS QUE GOLIATS?" UN CASO SOBRE EL PODER DE LAS PEQUEÑAS \\ EMPRESAS PARA SER MÁS INNOVADORAS EN COMPARACIÓN CON LAS EMPRESAS MÁS \\ GRANDES DURANTE UNA PANDEMIA GLOBAL
}

Tyrha M. Lindsey-Warren, Ph. D. ${ }^{\text {a }}$

Classification: Conceptual paper

Received: May 18, 2020 / Revised: August 7, 2020 / Accepted: October 19, 2020

\begin{abstract}
The biblical story of David and Goliath depicts how an ordinary man was confronted with a tremendous challenge and had to respond in an immediate and effective manner in order to be victorious. This same sentiment embodied in the story of David and Goliath holds true in the context of business innovation and reimagination among small firms, especially right now during the Coronavirus Global Pandemic. This conceptual paper discusses how large firms, or Goliaths, have proven track records and tremendous amounts of muscle and resources to support innovation, R\&D, and even unexpected emergencies. Yet, small firms, or Davids, often suffer from the liability of newness, sudden change in the business environment, and do not have the same resources to consistently finance on-going innovation or even operations. Nevertheless, we present a case that small firms, like David, can be victorious by being empowered as well as by leveraging their own creativity, resourcefulness, ingenuity, strategic innovation, and reimagination of their businesses during the current Global Pandemic.
\end{abstract}

Keywords: Small firms, pandemic, innovation, reimagination, empowerment

\section{Resumen}

La historia bíblica de David y Goliat describe cómo un hombre común se enfrentó a un tremendo desafío y tuvo que responder de manera inmediata y efectiva para salir victorioso. Este mismo sentimiento encarnado en la historia de David y Goliat es cierto en el contexto de la innovación empresarial y la reinvención entre las pequeñas empresas, especialmente en este momento durante la Pandemia Global de Coronavirus. Este trabajo conceptual analiza cómo las grandes empresas, o Goliat, tienen antecedentes probados y enormes cantidades de músculo y recursos para apoyar la innovación, la I + D e incluso las emergencias inesperadas. Sin embargo, las pequeñas empresas, o David, a menudo sufren la responsabilidad de la novedad, los cambios repentinos en el entorno empresarial y no tienen los mismos recursos para financiar constantemente la innovación o incluso las operaciones en curso. Sin embargo, presentamos el caso de que las pequeñas empresas, como David, pueden salir victoriosas si se les empodera y si aprovechan su propia creatividad, iniciativa, ingenio, innovación estratégica y reinvención de sus negocios durante la actual pandemia global.

Palabras clave: pequeñas empresas, pandemia, innovación, reinvención, empoderamiento 
"...And David put his hand in his bag, and took thence a stone, and slang it, and smote the Philistine (Goliath) in his forehead, that the stone sunk into his forehead; and he (Goliath) fell upon his face to the earth..."

From 1 Samuel-17:49 in the King James Version of the Bible

\section{Introduction}

On July 15, 2020, The New York Times reported that the Global Pandemic was hitting small businesses exceptionally hard. One in three small firms from around the world had to cut jobs in May due to the Coronavirus pandemic and nearly two out of three small firms reported lower sales in the past 30 days in comparison to the same time in 2019 (da Costa, 2020).

In Malcolm Gladwell's bestselling book, David and Goliath, the author states that when one is facing a tremendously challenging situation, one must ask him or herself, "Shall I play by the rules or follow my own instincts? Shall I persevere or give up?" (Gladwell, 2013, p. 5). In describing this biblical narrative, Gladwell continues to state that when one faces overwhelming challenges and insurmountable odds, like David, often the end result is that one produces beauty and greatness (Gladwell, 2013, p. 6) due to the ability to innovate as well as reimagine the possibilities of the circumstances.

Gladwell's same sentiment embodied in the story of David and Goliath holds true in the context of corporate innovation among small firms, especially right now during the Coronavirus Global Pandemic. Large firms, or Goliaths, have proven track records and tremendous amounts of muscle and resources to support innovation, $\mathrm{R} \& \mathrm{D}$, and even unexpected emergencies. Small firms, or Davids, often suffer from the liability of newness, sudden change, and do not have the same resources to consistently finance on-going innovation. Yet, these small firms, like David, can achieve enormous value and greatness at the end of the day by leveraging their relationships with large firms as well as through their own creativity, resourcefulness, ingenuity, strategic innovation and their ability to reimagine their businesses. The latter is definitely needed by small firms given the current business environment of operating during a Global Pandemic.

The circumstances under which small firms are most likely to be relatively strong innovators are rooted in understanding that small firms must have 1) the knowledge of the innovative opportunity within the business environment they are operating within and the role of technology, 2) the "control" of R\&D and technology as an on-going process, 3 ) the core technological competency, social factors, and absorptive capacity, both in-house and through supportive relationships and alliances, and 4) the willingness to empower themselves, their customers, and community by defining their unique voice and taking advantage of their distinctiveness. Hence, the focus of this conceptual paper is to discuss how small firms can achieve sustainability and survival in a global pandemic environment as well as be relatively more innovative and reimaginative than large firms.

\section{The Role of Reimagination and Purposeful Innovation}

Drucker (2014) believed that "entrepreneurs innovate" and that "innovation is a specific instrument" for business owners (p. 30). Hence, all too often, innovation is presented as the answer for societal challenges (Joly, 2019). However, the ability to reimagine takes innovation to a higher and perhaps a more disruptive level. This is due to the fact that being able to reimagine one's business operations means taking the time to rethink and reinterpret "how" the business can operate within a new environment or within a set of unique circumstances.

This also requires small firms to rethink the primary tenets of innovation defined by a sequence of characteristics including "technology centeredness, market relatedness, competition, entrepreneurialism, diffusion, exclusivity, and creative destruction, and above all by the belief that innovation is always good" (Joly, 2019, p. 1).

Drucker also believes in "purposeful innovation" (Drucker, 2014, p. 30), which implies that successful entrepreneurs create value (either economic or social) as well as work to make a contribution to society (Drucker, 2014). Within this framework, the entrepreneur can view him or herself as the "co-creative partner" in safeguarding the "vitality and health of all the communities (and stakeholders) he or she belongs to" (Sanford, 2011, p. 1). Within this context, the entrepreneur can also develop the ability to see him or herself gaining perspective and intelligence in order to become a positive agent for change in 
creating healthier internal and external systems, including the manner in which he or she manages the business (Sanford, 2011). Overall, the role of reimagination of the small firm's business requires the entrepreneur to be open to non-technical sources of innovation, be empowered, develop skills that are ambidextrous, as well as shift from a culture of novelty to a culture of incrementalism and maintenance (Joly, 2019, p. 18; Seebode et al., 2012).

\section{The Beauty of Empowerment}

Employing an empowerment strategy can illuminate a small firm's soul as well as its message to consumers that together they can achieve whatever they put their minds to (Bahadur, 2014), which is certainly what David did. Therefore, empowering consumers enables small firms to offer control and power, which can be a promising source of creating a competitive advantage (Hunter et al., 2008). This rationale comes from the thought that firms can consciously institute an empowerment strategy within their marketing of products and services to consumers, if they believe it will lead to increased consumer satisfaction. If consumer satisfaction is positively impacted, the small firms will experience increased sales, which in the end, creates a competitive advantage for the firm (Lindsey, 2017).

The marketing literature relating to consumer empowerment primarily focuses on choice (Gourville \& Soman, 2000), control (Langer, 1983), decision-making (Iyengar \& Lepper, 2000), and power (Conrad et al., 2006; McGregor, 2005). In a financial literacy context, McGregor (2005) suggests that empowerment is me-power and involves giving the receiver the perception that one has the inner power and strength to take action. Specifically, the author believes that when consumers are empowered, they are able to find their own self-worth and see value in their potential and personal abilities to ultimately control their destiny (McGregor, 2005).

It also leads to consumers discovering their reflective state, which can be referred to as an "aha" moment (McGregor, 2005). Wathieu et al. (2002) looked at consumer empowerment within the overall context of consumer control and choice. Ultimately, when small firms can empower its consumers, they are giving them the dominant position in their decision-making processes. For small firms, the beauty of empowerment is that it has the ability to emotionally pull at the heartstrings of its consumers. Empowerment also has the power to touch the soul and enable a small firm, along with its stakeholders, to see unimaginable possibilities and positive outcomes.

Hence, when working within a Global Pandemic, embracing these types of attributes and skills is imperative for a small firm.

\section{The Technological Environment That Supports Business Opportunity for Small Firms}

Upon entering the battle field with Goliath, David understood that he was navigating uncharted territory. Therefore, he brought with him his own creativity and knowledge of how he knew he could be successful in such an environment, if given the opportunity. Small firms must also exude this type of behaviour and willingness to embrace uncertainty, especially now during the current Global Pandemic. In order to be successful, small firms must know the role of technology in their business environment, which helps them match their technological strengths with technological opportunities. This type of "real world" thinking is similar to Schumpeter who believed that competition takes place through innovation and by introducing new products and services. Moreover, in the spirit of the "Schumpeter hypothesis," large firms doing business in a concentrated market can have an advantage in the areas of R\&D and patent output due to their size (Cohen, 1995). Schumpeter believed that large firms have a type of temporary market power to have the resources to invest in R\&D. Currently, ex-post market power on innovative activity points out that appropriability conditions must be considered. Moreover, large firms can also get stuck within this sameness manner of operating. Specifically, they can lack the capabilities to explore alternatives or "think out of the box" (Seebode et al., 2012).

Levin et al. (1985) discovered in their research that technological opportunity and appropriability within the market have positive effects on outputs and effort regarding small firm's innovative operations. Essentially, there must be a balance between the two. This type of thinking goes against traditional thinking that large firms are more innovative due to their large $\mathrm{R} \& \mathrm{D}$ expenditures and unionization of workers, among other variables. However, Acs and Audrestsch found that those variables negatively impacted innovation. They also discovered that small firms respond differently in economic and technological environments (Acs \& Audrestsch, 1988). Skilled labour, top management prowess, social factors, astute strategic planning, and the elasticity of concentration were positively correlated to small firm innovations (Eisenhardt \& Schoonhoven, 1996). Their research also revealed that within an industry where large firms are producing a great deal of innovations, more innovative activity will come from small firms (Acs \& Audrestsch, 1988).

Additional research that examines innovative output by small firms also recognizes that they produce more R\&D output. Bound et al. (1984) looked at patent activity and discovered that the patents produced by small firms 
were higher than those produced by large firms. Research by Pavitt et al. (1987) revealed that the U-shaped pattern for R\&D productivity seemed to decrease with firm size. Moreover, Chrisman et al. (2015) suggest that small firms must leverage that ability and willingness to innovate. They must dismiss core rigidities and be willing to exploit new knowledge to compete effectively (Eisenhardt \& Schoonhoven, 1996; Seebode et al., 2012).

\section{The "Control" of R\&D and Technology As An On-Going Process Within Small Firms}

As David prepared to meet Goliath, he controlled for what he needed to be successful. He did not have the budget to afford the finest battle wear. However, he had his network of relationships and natural resources that he could use to equip himself with the tools that he needed. Like David, within the innovation and R\&D context, especially given the backdrop of a Pandemic, small firms have problems to solve and issues to address with a sense of urgency. Having the ability and capacity to control R\&D within a small firm is essential for its sustainability and survival. In order to achieve this control, a small firm must get the balance of coordination and appropriability right. From skilled labour employees to the coordination of projects and contracts, an integrated and highly formed network is created within the small firm where every part is dependent on the other. This type of initiative and responsiveness of small firms lends itself to good innovative activity amongst all of its business networks, both domestically and internationally. Without any type of control, small firms would find it very difficult to get any type of return on their newly created knowledge and network of alliances.

The dependent nature of market structure and $R \& D$ intensity within small firms is a significant factor to the small firm's innovative success. R\&D employment, along with appropriate ROI on R\&D output, are important characteristics that can determine innovative behaviour (Cohen, 1995). Due to the fact that small firms have all of these aspects of R\&D intertwined and interrelated, primarily due to their size, the R\&D intensity, and its subsequent output, ultimately become tremendous assets to small firms.

Essentially, fifty percent of a small firm's innovative $R \& D$ intensity is due to many other aspects of its operations rather than size (Cohen, 1995). Given the notion of sectoral taxonomy, small firms can be innovative through their absorptive capacity. They can also be innovative through their on-going relationships with large firms. Hence, the key to such alliances, is that small firms can obtain immediate and enhanced legitimacy (Eisenhardt \& Schoonhoven, 1996). Such alliances can also help small firms increase their market power and operations for future and potential investments (Eisenhardt \& Schoonhoven, 1996). At the same time, significant social factors must not be ignored between such alliances when small firms are in a vulnerable position. These prominent social factors include the evolution of awareness, mutual knowledge, and trustworthiness, which are central to the creation of cooperative relationships (Eisenhardt \& Schoonhoven, 1996, p. 138).

Another aspect of a small firm's success is its diversification and developing ambidexterity. This type of strategy enables a small firm to be more innovative and reimagine its business because it gives the firm more opportunities to exploit its tacit capabilities (Cohen, 1995; Seebode et al., 2012). Moreover, within this type of environment, the small firm can find its own niche, which can also enable it to successfully survive. This type of technological opportunity requires low levels of R\&D investment by the small firm.

\section{The Competencies and Absorptive Capacity, Both In-House and Through Supportive Partnerships of Small Firms}

Upon facing the enormous challenge of how to appropriately respond to Goliath, David leveraged the science of how a sling and stone work together to essentially turn it into an innovative technology and achieve success. Leveraging science to create unique and/or niche technology to achieve market growth is truly what small firms do in order to produce more innovative activity than large firms. Often, small firms see opportunities and/or needs that are not obvious to large firms due to the unique lens they use to view both opportunities and problems. This absorptive capacity could be due to their localized perspective or network of relationships. Moreover, depending on how the small firm was created, the Founder may bring a distinctive set of core competencies to the firm. $\mathrm{He}$ or she may also bring past working relationships with large firms to the small firm and create a niche. From an innovation standpoint, technological competence theory may apply to small firms. Within this theoretic context, robust technological capacity can lower costs per unit, increase product quality, and improve profit margins when small firms enter a new market (Cantwell, 1991).

Small firms are also less likely to imitate. This is due to the tremendous skill that small firms bring to the industry. Or, according to Penrose (1959), small firms may have inherited resources. Typically, it is the small firm that has the focus and the dynamic capabilities (Teece et al., 1990) to create ground-breaking innovations. Essentially, at this level, they are the leader in the field. Therefore, small firms have no need to imitate others. 
In addition, small firms must also have managers at all levels who exude an entrepreneurial business acumen (Cantwell, 1991). Chandler (1990) refers to this as vast and dynamic capabilities within the organization. Small firms can also be quick and nimble, which enables them the ability to react fast to opportunities and/or to problems, as well as leverage the results of their responses to their advantage.

Inter-industry relationships of small firms with other partners, as well as with large firms, can also allow small firms to have a competitive advantage. These relationships may allow small firms to offer better pricing, develop on-going R\&D operations that are less formalized, and take greater risks because the network of alliances will absorb the risk versus just one firm. Hence, this diagram illustrates the unique outcomes of small firms who need to manage all of their tangible and intangible assets when operating within an uncertain environment (Figure 1).

\section{Conclusion}

Given the current business climate of operating during the Coronavirus Global Pandemic, like David, the best resource a small firm has is itself. The small firm succeeds the most when it has strong ties with large firms and understands the environment it is operating within. It was recently said in new coverage that the major four big tech companies, Facebook, Amazon, Google and Apple, were once led by empowered entrepreneurs who were models of American scrappy ingenuity. However, during the current Pandemic, these companies have truly realized their dominance and are now collectively valued at almost $\$ 5$ trillion dollars (Selyukh, 2020). Hence, there is a strong case that during uncertain times, the small firm can equip itself with the technological competencies, absorptive capacity, creativity, strategy, courage, and perhaps a little bit of luck, that will enable the firm to develop more revolutionary innovations than Goliath could ever dream of doing!

\section{References}

Acs, Z. J., \& Audretsch, D. B. (1988). Innovation in large and small firms: An empirical analysis. The American Economic Review, 678-690.

Bahadur, N. (2014). Femvertising' Ads are empowering women - And making money for brands (accessed on December 1, 2014). http://www.huffingtonpost. com/2014/10/02/femvertising-advertising-empowering-women_n_5921000.html

Bound, J., Cummins, C., Griliches, Z., Hall, B., \& Jaffe, A. (1984). Who does R\&D and who patents? $R \& D$, Patents, and Productivity, 21-54.

Cantwell, J. (1991). The theory of technological competence and its application to international production. In D. McFetridge (Ed.), Foreign investment, technology and economic growth (pp. 33-67). Routledge.

Chandler Jr, A. D. (1990). Scale and scope: The dynamics of industrial capitalism. Harvard University Press.

Chrisman, J., Chua, J., De Massis, A., Frattini, F., \& Wright, M. (2015). The ability and willingness paradox in family firm innovation. Journal of Product Innovation Management, 32(3), 310-318.

Cohen, W. M. (1995). Empirical studies of innovative activity. Handbook of the Economics of innovation and technological change (pp. 182-264).

Conrad, H., Caldwell, P., \& Caldwell, M. (2006). Self-Empowerment and consumption: Consumer remedies for prolonged stigmatization. European Journal of Marketing, 40 (September), 1031-1048.

da Costa, A. N. (2020). Coronavirus cost jobs at a third of small firms open in May: Global Facebook survey. The New York Times. Available at https://www. nytimes.com/reuters/2020/07/15/business/15reuters-health-coronavirus-small-business.html?searchResultPosition=1[Accessed on July 25, 2020].

Drucker, P. (2014). Innovation and entrepreneurship: Practices and principles. Routledge.

Figure 1. The Case for Small Firms When Operating Within the Current Coronavirus Global Pandemic
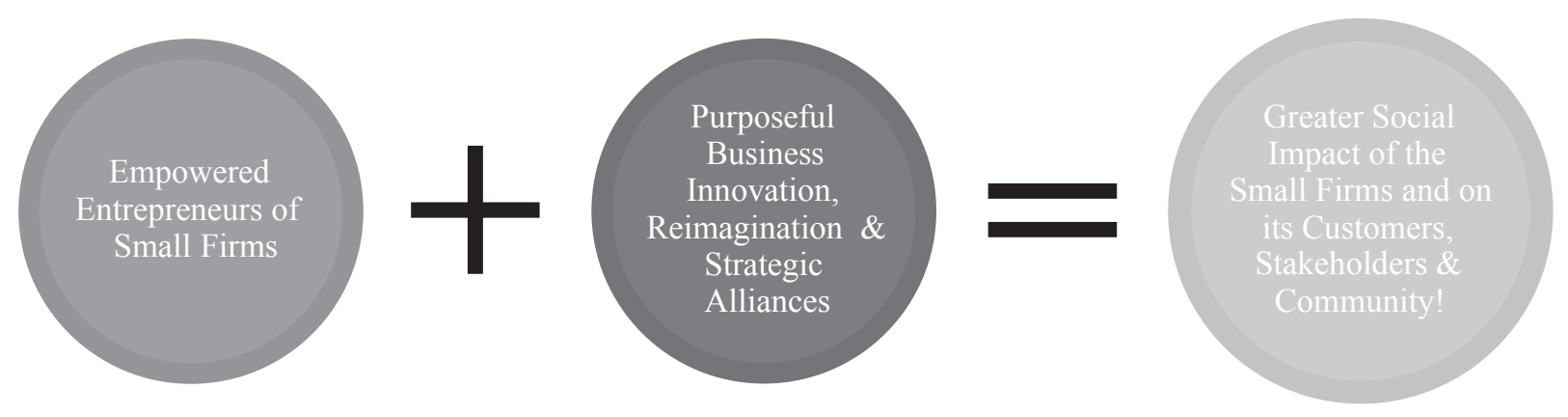
Eisenhardt, K. M., \& Schoonhoven, C. B. (1996). Resource-based view of strategic alliance formation: Strategic and social effects in entrepreneurial firms. Organization Science, 7(2), 136-150.

Elliott, J. W. (1971). Funds flow vs. expectational theories of research and development expenditures in the firm. Southern Economic Journal, 409-422.

Gladwell, M. (2013). David and Goliath. Little, Brown and Company.

Gourville, J. T., \& Soman, D. (2000). Is more choice always better. The effect of assortment type on consumer choice, arbeitspapier. Harvard University.

Hunter, G. L., Garnefeld, I., Kucuk, U., Gau, R., \& Viswanathan, M. (2008). When does consumer empowerment lead to satisfied customers? Some mediating and moderating effects of the empowerment-satisfaction link. Journal of Research for Consumers, 15(July), 1-14.

Iyengar, S. S., \& Lepper, M. R. (2000). When choice is demotivating: can one desire too much of a good thing? Journal of Personality and Social Psychology, 76(6), 995-1006.

Joly, P. B. (2019). Reimagining innovation. In S. Lechevallier, Innovation beyond technology (pp. 25-46). Springer.

Langer, E. J. (1983). The psychology of control. Sage Publications.

Levin, R. C., Cohen, W. M., \& Mowery, D. C. (1985). R \& D appropriability, opportunity, and market structure: New evidence on some Schumpeterian hypotheses. The American Economic Review, 75(2), 20-24.

Lindsey, T. M. (2017). Empowered storytelling? An examination of narrative transportation and empowerment in storytelling and its impact on millennial consumers. Dissertation. Rutgers University-Graduate School-Newark.
McGregor, S. (2005). Sustainable consumer empowerment through critical consumer education: A typology of consumer education approaches. International Journal of Consumer Studies, 29 (September), $437-$ 447.

Pavitt, K., Robson, M., \& Townsend, J. (1987). The size distribution of innovating firms in the UK: 1945-1983. The Journal of Industrial Economics, 297-316.

Penrose, E. T. (1995). The theory of the growth of the firm. Oxford University Press.

Sanford, C. (2011). The responsible business: Reimagining sustainability and success. John Wiley \& Sons.

Seebode, D., Jeanrenaud S., \& Bessant, J. (2012). Managing innovation for sustainability. $R \& D$ Management, 42(3), 195-206.

Selyukh, A. (2020). CEOs of 4 tech giants to testify before house panel hearing. National Public Radio's Morning Edition. Available at https://www.npr. org/2020/07/29/896588216/ceos-of-4-tech-giants-totestify-before-house-panel-hearing [Accessed on August 2, 2020].

Teece, D. J., Pisano, G. P., \& Shuen, A. (1990). Firm capabilities, resources, and the concept of strategy: Four paradigms of strategic management. University of California at Berkeley, Centre for Research in Management, Consortium on Competitiveness \& Cooperation.

Wathieu, L., Brenner, L., Carmon, Z., Chattopadhyay, A., Wertenbroch, K., Drolet, A., Gourville, J., Muthukrishnan, A. V., Novemsky, N., Ratner, R. K., Wu, G. (2002). Consumer control and empowerment: A primer. Marketing Letters, 13(August), 297-305. 